\title{
Penerapan Teknik Taking Notes untuk Meningkatkan Kemampuan Membaca Mahasiswa PBA IAIM NU Metro Lampung
}

\author{
Muhammad Syaifullah \\ Institut Agama Islam Ma'arif NU Metro Lampung \\ muhammadsyaifullah121285@yahoo.co.id \\ DOI: http://dx.doi.org/10.18326/lisania.v2i2.139-159
}

\begin{abstract}
This study aims to describe the learning implementation of Arabic text reading with cognitive strategies of taking notes techniques and to describe the results of increased mastery of Arabic text reading of Arabic Education students at IAIM NU Metro Lampung through the use of cognitive strategies with taking notes techniques. This research is conducted at IAIM NU Metro Lampung. The research subjects are students in the fourth semester of the 2017/2018 academic year, totaling 11 students. The research design uses Classroom Action Research, namely planning, implementation, observation and reflection. This research is conducted in 2 cycles, with 2 meetings each cycle. The instruments used are test questions, observation sheets and interview guidelines. The results show that: (1) the ability of students to read Arabic texts with taking notes techniques has increased. At the first meeting of the first cycle, it is found that in the loud reading session, most students are less total in making a vote, but at the second meeting there has been an increase. (2) students also feel helped in understanding the contents of Arabic text by taking notes techniques because this technique is very simple and easy to apply. From the data obtained, it is known that the ability of students to understand the Arabic text has increased, namely before the action of student learning outcomes is carried out on average only 45\% after the end of the action in the first cycle an average of $79 \%$, and cycle II an average of $86 \%$.
\end{abstract}

Keywords: Cognitive Strategies, Taking Notes Techniques, Arabic Text Reading

\begin{abstract}
Abstrak
Penelitian ini bertujuan untuk mendeskripsikan pelaksanaan pembelajaran membaca teks bahasa Arab dengan strategi kognitif teknik taking notes dan mendeskripsikan hasil peningkatan penguasaan membaca teks bahasa Arab mahasiswa Pendidikan Bahasa Arab IAIM NU Metro Lampung melalui penggunaan strategi kognitif dengan teknik taking notes. Penelitian ini dilakukan di IAIM NU Metro Lampung, Subjek penelitiannya adalah mahasiswa semester IV tahun ajaran 2017/2018 yang berjumlah 11 mahasiswa. Rancangan penelitian menggunakan penelitan tindakan kelas (Classroom Action Research), yaitu perencanaan, pelaksanaan, observasi dan refleksi. Penelitian ini dilakukan dengan 2 siklus, setiap siklusnya terdapat 2 pertemuan. Instrumen yang digunakan adalah soal tes, lembar observasi dan pedoman wawancara. Hasil penelitian menunjukan bahwa: (1) kemampuan mahasiswa dalam membaca teks bahasa Arab dengan teknik taking notes mengalami peningkatan. Pada pertemuan pertama siklus I diketahui pada sesi membaca nyaring sebagian besar mahasiswa kurang total dalam mengeluarkan suara, namun di pertemuan ke dua sudah mengalami peningkatan. (2) mahasiswa juga merasa terbantu dalam memahami isi teks bahasa Arab dengan teknik
\end{abstract}


taking notes karena teknik ini sangat simpel dan mudah diterapkan. Dari data yang di dapatkan diketahui bahwa kemampuan mahasiswa dalam memahami teks bahasa Arab mengalami peningkatan, yakni sebelum dilakukan tindakan hasil belajar mahasiswa rata-rata hanya $45 \%$ setelah akhir tindakan pada siklus I rata-rata $79 \%$, dan siklus II rata-rata $86 \%$.

Kata Kunci : Strategi Kognitif, Teknik Taking Notes, Membaca Teks Bahasa Arab

\section{Pendahuluan}

Peningkatan mutu pendidikan dirasakan sebagai suatu kebutuhan bangsa yang ingin maju dengan keyakinan bahwa pendidikan yang bermutu dapat menunjang pembangunan di segala bidang. Oleh karena itu pendidikan perlu mendapat perhatian yang besar agar kita dapat mengejar ketertinggalan di bidang ilmu pengetahuan dan teknologi yang mutlak kita perlukan untuk mempercepat pembangunan dewasa ini. Karena itu pendidikan yang bermutu perlu mendapat perhatian yang serius dari pemerintah. Dunia pendidikan saat ini menjadi sorotan utama pemerintah maupun dunia internasional, terutama pada kurangnya variasi strategi pembelajaran pada proses PBM.

Effendy (2009: 8) mengatakan, dalam pengajaran bahasa ada tiga istilah yang perlu dipahami pengertian dan konsepnya secara tepat, yakni pendekatan, metode dan teknik. Pendekatan adalah seperangkat asumsi berkenaan dengan hakekat bahasa, dan belajar-mengajar bahasa. Metode adalah rencana menyeluruh penyajian bahasa secara sistematis berdasarkan pendekatan yang ditentukan. Sedangkan teknik adalah kegiatan spesifik yang diimplementasikan dalam kelas, selaras dengan metode dan pendekatan yang telah dipilih. Dengan demikian, pendekatan bersifat aksiomatis, metode bersifat procedural, dan teknik bersifat oprasional.

Jika penerapan metode pembelajaran untuk semua kompetensi hanya menggunakan metode ceramah dan tanya jawab sebagai metode utama proses belajar akan terasa membosankan dan apabila seorang siswa telah mengalami kebosanan atau kondisi mental yang kurang siap untuk belajar maka apa yang ia pelajari tidak akan dapat diserap secara maksimal dan penyerapan materi yang kurang maksimal ini akan berdampak pada pemahaman materi selanjutnya, oleh sebab itu perlulah kiranya melakukan suatu variasi dalam metode pembelajaran agar siswa tidak bosan dan dapat belajar dalam kondisi yang prima. Untuk itu diperlukan sebuah strategi belajar baru yang lebih menarik dan tidak membosankan. Sebuah strategi yang membantu siswa 
dalam memahami pelajaran khususnya dalam memahami teks berbahasa Arab dalam pelajaran bahasa Arab.

Oxford (dalam Nurhidayati, 2005: 29) memaparkan tentang gambaran umum strategi belajar bahasa yang dikategorikan atas dua strategi yaitu strategi langsung (direct strategies) dan strategi tidak langsung (indirect strategies). Strategi langsung meliputi tiga strategi pembelajaran yaitu strategi memory (memory strategies), strategi kognitif (cognitive strategies), dan strategi kompensasi (compensation strategies). Salah satu strategi pengajaran yang berasosiasi dengan strategi langsung adalah strategi kognitif.

Strategi kognitif menurut Gagne (dalam Yamin, 2008: 5) adalah kemampuan internal seseorang untuk berfikir, memecahkan masalah, dan mengambil keputusan. Kemampuan strategi kognitif menyebabkan proses berfikir unik di dalam menganalisa, memecahkan masalah, dan didalam mengambilkan keputusan. Kemampuan dan keunikan berfikir tersebut sebagai executive control, atau disebut dengan control tingkat tinggi, yaitu analisa yang tajam, tepat dan akurat. Hal ini dapat kita lihat dalam kehidupan dunia politik Indonesia kini, mereka yang memiliki kemampuan kognisi yang tinggi begitu mudah memecahkan masalah akan tetapi begitu mudah pula membalik fakta, konsep, dan prinsip atas kepentingan politik yang mereka dukung, demikian sebaliknya kemampuan kognisi rendah mereka tiada pernah mengambil terobosan hanya sebagai hak turut saja.

Strategi kognitif sendiri bisa diaplikasikan melalui beberapa teknik, yaitu; (1) pelatihan (practicing), (2) menerima dan mengirim pesan (receiving and sending messeges), (3) menganalisis dan menyimpulkan (analyzing and reasoning), dan (4) penciptaan konsep atau struktur untuk bahan masukan atau bahan keluaran (creating structure for input and output). Di dalam creating structure for input and output inilah terlahir teknik membuat catatan taking notes, membuat ringkasan (summarizing), dan memberi tanda (highlighting).

Membuat catatan taking notes merupakan salah satu teknik yang tepat untuk menyempurnakan pembelajaran masa kini khususnya dalam maharah qira'ah untuk memahami isi teks bahasa Arab. Nurhidayati dkk (2005: 35) menyatakan bahwa membuat catatan merupakan proses yang sangat penting dalam kegiatan membaca/menyimak. Dalam kegiatan membaca/menyimak sebuah cerita misalnya 
guru dapat menyiapkan sebuah tabel yang berisi tentang hal-hal penting dari cerita yang disimak atau dibacanya.

Berdasarkan uraian di atas, maka peneliti bermaksud untuk mengangkat masalah ini dalam suatu penelitian tindakan kelas untuk meningkatkan kemampuan membaca teks bahasa Arab mahasiswa Pendidikan Bahasa Arab IAIM NU Metro Lampung dengan judul "Penerapan Strategi Kognitif Dengan Teknik Taking Notes Untuk Meningkatkan Kemampuan Membaca Teks Bahasa Arab Mahasiswa Pendidikan Bahasa Arab IAIM NU Metro Lampung".

\section{Metode Penelitian}

Jenis penelitian yang dilaksanakan adalah jenis penelitian tindakan kelas (Classroom Action Research). Menurut Wiriaatmadja dalam Ristianah (2007) penelitian tindakan kelas adalah bagaimana sekelompok guru dapat mengorganisasikan kondisi praktek pembelajaran mereka, dan belajar dari pengalaman mereka sendiri. Penelitian tindakan kelas dicobakan sebagai gagasan perbaikan dalam praktek pembelajaran dan melihat pengaruh yang nyata dari upaya tersebut.

Sedangkan menurut Jono, \& Tisno (dalam Wahidmurni:2008), PTK merupakan suatu kajian yang bersifat reflektif oleh pelaku tindakan yang dilakukan untuk meningkatkan kemampuan rasional dari tindakan-tindakan yang dilakukannya itu, serta untuk memperbaiki kondisi-kondisi dimana praktek-praktek pembelajaran tersebut dilakukan. Jadi tujuan dari penelitian tindakan kelas ini adalah untuk memperbaiki pelaksanaan praktek dalam proses pembelajaran dengan mengoptimalkan media, metode, startegi pembelajaran dimana perbaikan tersebut diharapkan dapat meningkatkan hasil pembelajaran siswa.

Pelaksanaan penelitian tindakan kelas dilakukan melalui beberapa siklus dimana setiap siklus terdiri dari empat tahap yaitu: 1) perencanaan, 2) pelaksanaan, 3) pengamatan, 4) refleksi. Karena untuk menentukan jumlah siklus, peneliti harus melihat tingkat keberhasilan dari siklus yang sudah dilaksanakan. Apabila dalam siklus 1 proses pembelajaran sudah mencapai tujuan yang diharapkan, maka peneliti cukup menggunakan satu siklus saja. Tetapi apabila dalam siklus 1 masih terdapat kekurangan dan perlu adanya perbaikan, maka peneliti perlu melanjutkan ke siklus berikutnya. 


\section{Tahap - Tahap Penelitian}

\section{Siklus 1}

Siklus 1 ini mencakup 4 tahapan, yakni: a) tahap perencanaan, b) tahap pelaksanaan, c) tahap pengamatan, dan d) tahap refleksi.

\section{Tahap Perencanaan}

Pada tahap ini dilakukan kegiatan yaitu (1) melakukan pertemuan awal dengan dosen mata kuliah bahasa Arab (Qiro'ah) dan menyampaikan hal - hal mengenai perencanaan penelitian yang akan dilaksanakan. (2) menyiapkan rencana pembelajaran (3) menentukan sumber data. Pada tahap ini kegiatan yang dilakukan adalah: menyusun Rencana Pembelajaran Semester (RPS) pokok bahasan " tempat tinggal“ (الهوايات) dan menyiapkan media kartu bergambar dan tabel membuat catatan yang akan digunakan dalam proses pembelajaran baik dalam penyampaian materi maupun dalam penerapan teknik taking note.

\section{Tahap Pelaksanaan Tindakan}

Tahap pelaksanaan tindakan dilaksanakan dua kali pertemuan yang meliputi: pertemuan ke (1) penyajian materi qira'ah teks bahasa Arab dan penerapan teknik taking notes, dan (2) evaluasi dan penghargaan.

\section{Pertemuan Pertama}

Pada pertemuan pertama ini dosen menyajikan materi qira'ah teks bacaan baru yang mencakup tema (الهو ايات) dalam bahasa Arab. Pada tahap penyajian kelas ini peneliti membacakan materi qira'ah teks bacaan baru yang mencakup tema (الهوايات) dalam bahasa Arab dan kemudian seluruh mahasiswa mengikuti, meminta mahasiswa memimpin kelas untuk membaca bersama-sama, memberikan kesempatan kepada mahasiswa untuk bertanya mengenai kosakata yang sulit, bersama-sama membahas kosa kata yang sulit. Kemudian dosen menerapkan teknik taking notes. Sebelum memulai kegiatan taking notes, dosen menjelaskan langkahlangkah dalam strategi kognitif teknik taking notes disertai dengan simulasi sebagai penjelas. Tahap pertama, mahasiswa mulai bekerja untuk memahami teks bacaan yang sudah diberikan pada pertemuan sebelumnya selama batas waktu yang telah ditentukan. Tahap kedua, dosen membagikan lembaran tabel taking notes dan kemudian mahasiswa mengisi tabel tersebut sesuai dengan teks. 


\section{Pertemuan Kedua}

Pada pertemuan kedua ini dosen mengajak mahasiswa mengulang kembali membaca teks/materi yang telah disampaikan pada pertemuan sebelumnya. Setelah selesai pada kegiatan membaca nyaring dosen memberi tugas/kuis kepada mahasiswa sebagai bahan evaluasi. Dan kemudian dosen memberikan penghargaan pada mahasiswa yang telah berhasil mengumpulkan tugasnya paling cepat dan paling benar, mendapatkan reward yang telah disepakati sebelumnya. Tahap terakhir, dosen bersama mahasiswa membuat kesimpulan pelajaran.

\section{Tahap Pengamatan atau Pelaksanaan Observasi Tahap 1}

Observasi dilakukan selama proses pembelajaran berlangsung. Pada tahap ini dilakukan observasi terhadap aktivitas belajar mahasiswa dan keadaan kelas selama pembelajaran berlangsung.

\section{Tahap Refleksi}

Berdasarkan data yang diperoleh dari tindakan 1 maka data diolah atau dianalisa. Peneliti mengamati hasil tindakan 1 sebagai bahan pertimbangan apakah siklus sudah mencapai kriteria atau tidak. Hasil analisis data yang dilaksanakan dalam tahap ini dipergunakan sebagai acuan untuk merencanakan siklus berikutnya.

\section{Siklus 2}

Setelah merefleksi siklus 1, maka dapat dilanjutkan kesiklus 2 jika belum tercapai ketuntasan belajar baik secara individu maupun klasikal. Pada siklus 2 ini pada hakekatnya adalah melengkapi apa yang kurang dan perlu diperbaiki pada siklus 1 guna menghasilkan hasil akhir atau kesimpulan penelitian. Siklus 2 dilaksanakan seperti siklus 1 dan dilakukan selama 2 kali pertemuan.

\section{Lokasi dan Subyek Penelitian}

Penelitian ini dilaksanakan di IAIM NU Metro Lampung pada semester IV. Subjek penelitian adalah mahasiswa semester IV yang berjumlah 11 mahasiswa. Karena penelitian ini merupakan penelitian tindakan kelas maka subjek yang diambil hanya satu kelas saja. 


\section{Data dan Sumber Data}

Jenis data dalam penelitian ini dikelompokkan menjadi dua yaitu: data utama yang meliputi nilai tes awal (pretes) dan hasil tes tiap siklus (postes) dan data pendukung, mencakup respon mahasiswa setelah diterapkan strategi kognitif dengan teknik taking notes berupa uraian deskriptif yang berasal dari wawancara, catatan lapangan, ketepatan dosen dalam menerapkan rencana pembelajaran, dan aktivitas mahasiswa selama kegiatan pembelajaran dengan menggunakan teknik taking notes. Adapun sumber data dalam penelitian ini meliputi mahasiswa pendidikan bahasa Arab semester IV yang berjumlah 11 mahasiswa IAIM NU Metro Lampung.

\section{Pengertian Strategi Kognitif}

Oxford (dalam Nurhidayati, 2005: 29) memaparkan tentang gambaran umum strategi belajar bahasa yang dikategorikan atas dua strategi yaitu strategi langsung (direct strategies) dan strategi tidak langsung (indirect strategies). Strategi langsung meliputi tiga strategi pembelajaran yaitu strategi memory (memory strategies), strategi kognitif (cognitive strategies), dan strategi kompensasi (compensation strategies).

Strategi kognitif menurut Gagne (Yamin, 2008: 5) adalah kemampuan internal seseorang untuk berfikir, memecahkan masalah, dan mengambil keputusan. Kemampuan strategi kognitif menyebabkan proses berfikir unik di dalam menganalisa, memecahkan masalah, dan didalam mengambilkan keputusan. Kemampuan dan keunikan berfikir tersebut sebagai executive control, atau disebut dengan control tingkat tinggi, yaitu analisa yang tajam, tepat dan akurat. Hal ini dapat kita lihat dalam kehidupan dunia politik Indonesia kini, mereka yang memiliki kemampuan kognisi yang tinggi begitu mudah memecahkan masalah akan tetapi begitu mudah pula membalik fakta, konsep, dan prinsip atas kepentingan politik yang mereka dukung, demikian sebaliknya kemampuan kognisi rendah mereka tiada pernah mengambil terobosan hanya sebagai hak turut saja.

Strategi kognitif merupakan kapabilitas yang mengatur cara bagaimana siswa mengelola belajarnya, ketika mengingat-ingat, dan berfikir, ia juga merupakan proses pengendali atau pengatur pelaksana tindakan. Strategi kognitif mempengaruhi perhatian siswa terhadap stimulus-stimulus, skema penyusunan sandi yang dilakukan siswa, dan tumpukan informasi yang disimpan dalam ingatan. Kapasitas ini juga mempengaruhi strategi siswa dalam mencari dan menemukan kembali hal-hal yang 
disimpan dan dalam mengorganisasi respon-respon. Gagne (dalam Yamin, 2008: 6) menyatakan bahwa strategi kognisi itu serupa dengan perilaku pengelolaan diri.

Gagne dan briggs (Yamin, 2008: 6) menyatakan suatu contoh strategi kognisi ialah proses inferensi atau induksi. Pengalaman dengan objek-objek atau kejadian-kejadian, dan disitu seseorang berusaha memperoleh penjelasan mengenai suatu gejala tertentu menghasilkan induksi. Berbeda dengan informasi verbal dan keterampilan intelek, yang ada kaitannya langsung dengan isi. Objek strategi kognitif ialah proses berfikir siswa sendiri. Ciri penting yang lain strategi kognitif tidak seperti keterampilan intelek, strategi itu tidak terpengaruh secara kritis oleh pelaksanaan pembelajaran, menit demi menit. Keterampilan strategi kognitif sampai pada derajat tertentu dapat dikembangakan menjadi lebih baik dengan pendidikan formal, dan siswa belajar dan berkembang dengan sendiri, berfikir menjadi mandiri Gagne (dalam Yamin, 2008:7).

\section{Teknik Pembelajaran Dengan Strategi Kognitif}

Nurhidayati, dkk (2005: 32) memaparkan bahwa "strategi ini bisa ditempuh melalui teknik practicing, receiving and sending messeges, analyzing and reasoning, dan creating structure for input and output".

Pada penelitian ini hanya dikhususkan pada penciptaan konsep atau struktur untuk bahan masukan atau bahan keluaran (creating structur for input and output). Strategi ini membantu siswa untuk mengorganisasikan informasi atau konsep dari bahasa yang dipelajari dan mendemonstrasikan pemahaman mereka secara nyata dan mempersiapkan untuk menggunakannya dalam kegiatan berbicara dan menulis. Ada tiga teknik untuk menerapkan strategi ini, yaitu: 1) Membuat catatan (taking notes). 2) Membuat ringkasan (summarizing). 3) Memberi tanda (highlighting).

\section{Pengertian Teknik Taking Notes}

Oxford (1990: 86-88) memaparkan bahwa membuat catatan taking notes ini adalah strategi yang sangat penting untuk mendengarkan dan membaca, tetapi pada umumnya/secara garis besar siswa tidak diajarkan menggunakannya dengan sempurna. Membuat catatan merupakan cara yang cukup maju digunakan pada tingkat keahlian yang tinggi (seperti ketika mendengarkan penjelasan guru).

Ada banyak cara berbeda dalam membuat catatan, bentuk yang paling sederhana atau mudah dan paling umum digunakan adalah catatan mentah yang masih belum 
terstruktur dan berubah. Agar catatan mentah tersebut bisa digunakan maka siswa harus kembali mengatur catatannya dengan menggunakan sistem lainnya sesegera mungkin. Cara lebih baik lainnya adalah dengan menggunakan "daftar belanja" atau “formasi T" seperti yang terdapat pada tahap awal dulu, yaitu menghilangkan catatan mentahnya. Keuntungan dari menggunakan salah satu dari yang disebutkan tadi adalah bisa membantu siswa mengatur apa yang mereka dengar ketika sedang mendengarkan, selain itu pula meningkatkan pemahaman dan kemampuan asli dalam menggabungkan informasi baru dan lama.

Format catatan atau daftar belanja benar-benar sangat mudah, akan tetapi hal itu benar-benar impose, beberapa pemilihan dari keteraturan dan organisasi pada materi yang dibicarakan. Termasuk juga menulis informasi cluster dan sets yang memiliki konsistensi internal atau makna.

Tabel 1. Bentuk catatan format T (Hamp-Lyons, 1983: 118).

\begin{tabular}{l:l}
\multicolumn{2}{c}{ Banana Cake } \\
\hline \multirow{3}{*}{ Ingredients need } & Lemon juice \\
& Milk \\
& Sugar \\
& bananas \\
& Vanilla \\
& Eggs (etc.) \\
& Large bowl \\
& Measuring cup \\
Equipment need & Fork \\
& Greased pan \\
& Spoon
\end{tabular}

Format T menggunakan materi yang sama seperti dalam daftar belanja. Format ini mirip dengan daftar belanja, tetapi dalam hal ini siswa diperbolehkan menggunakan/memberikan jarak pada kertas catatan mereka dalam cara yang lebih efektif. Langkah awal yaitu dengan menggambar huruf $\mathrm{T}$ besar di atas kertas di seluruh bagian kertas, kemudian ditulis tema utama/judul di atas garis, pada sisi sebelah kiri di garis vertikal di tulis kategori-kategori dasar/topik-topik yang sudah didiskusikan, pada sisi sebelah kanan digaris vertikal ditulis bagian-bagian yang detail, contoh yang spesifik, jawaban pertanyaan, atau komentar. 
Peta semantik juga merupakan format catatan yang bermanfaat, yang mensyaratkan siswa mengindikasikan kata/ide penting dan menghubungkannya dengan kata-kata yang berhubungan/ide-ide terkait yang dibentuk dengan anak panah dan garis-garis.

\section{Teknik Taking Notes dalam Pembelajaran Kemahiran Berbahasa}

Teknik membuat catatan bisa diintregasikan dengan aktivitas dan materi-materi kebahasaan regular seperti elemen alami dalam pembelajaran bahasa. Strategi meta kognitif yang digabungkan dengan pembuatan catatan adalah pengorganisasian yang didalamnya terdapat penjagaan buku catatan untuk menyatukan informasi bahasa baru dan perkembangannya. Suatu catatan seharusnya dijaga kerapiannya dalam beberapa gaya, a loose-leaf notebook bisa jadi cara terbaik. Bagi siswa yang menulis sesuatu yang subtansial dalam bahasa target, akan sangat membantu bila mengemukakan ide sesegera mungkin ketika ada dalam kepala. Oleh karena itu, buku catatan harus tetap dipegang sepanjang waktu.

Menurut Nurhidayati, dkk (2005:35) membuat catatan merupakan proses yang sangat penting dalam kegiatan membaca/menyimak. Dalam kegiatan membaca/ menyimak sebuah cerita misalnya guru dapat menyiapkan sebuah tabel yang berisi tentang hal-hal penting dari cerita yang disimak atau dibacanya. Misalnya:

Tabe 2. Contoh Tabel Taking Notes

Judul

\begin{tabular}{|c|c|c|c|c|}
\hline No & Nama Pemeran & Tempat Kejadian & $\begin{array}{c}\text { Waktu } \\
\text { Kejadian }\end{array}$ & Ciri-ciri Pemeran \\
\hline
\end{tabular}

Tabel tersebut merupakan arahan bagi siswa untuk mencatat hal-hal penting dalam cerita. Teknik membuat catatan ini tidak dimaksudkan untuk melatih kemampuan menulis tetapi ditekankan pada kemampuan memahami bacaan Nurhidayati, dkk (2005: 36). 


\section{Pengertian Membaca, Keterampilannya dan Jenis-Jenisnya}

Dalam kamus besar bergambar bahasa Indonesia (Nurhasanah, dkk, 2007: 36) membaca berasal dari kata dasar baca, membaca berarti memahami apa yang tertulis. Membaca adalah salah satu kemahiran pokok yang lazim dalam pembelajaran bahasa. Adapun kemahiran lain adalah kemahiran mendengarkan, kemahiran berbicara, dan kemahiran menulis.

Membaca adalah salah satu proses yang sangat penting untuk mendapatkan ilmu dan pengetahuan. Tanpa bisa membaca, manusia dapat dikatakan tidak bisa hidup di zaman sekarang ini, sebab hidup manusia sangat bergantung pada ilmu pengetahuan yang dimilikinya, sehingga untuk mendapatkan ilmu pengetahuan itu salah satunya dengan cara membaca.

Godman (dalam Al Abdullah, 2007:8) menyatakan bahwa membaca adalah aktifitas untuk memperoleh makna dari yang dicetak selama membaca menggunakan bahasa dengan kesempurnaannya.

Di zaman sekarang ini, sebagian besar pelajar atau mahasiswa kurang memiliki minat membaca, terutama membaca buku pelajaran. Ini diakibatkan karena sebagian dari mereka tidak memiliki metode dalam membaca, sehingga pada saat membaca timbul rasa malas, bosan, dan mengantuk. Menurut Nugraha (2008) ada beberapa hal yang dapat dilakukan supaya tercipta suasana membaca yang menyenangkan, antara lain: pilihlah waktu yang menurut kita sesuai untuk membaca, pilihlah tempat dan suasana yang sesuai untuk membaca, pastikan posisi membaca kita adalah posisi yang benar, siapkan juga hal-hal yang biasanya membantu kita dalam membaca.

Keterampilan membaca adalah salah satu dari empat keterampilan pokok dalam pembelajaran bahasa, disamping keterampilan menyimak, keterampilan berbicara dan keterampilan menulis. Membaca sebagai keterampilan dibedakan menjadi tiga macam keterampilan, yaitu: 1) Keterampilan mengenal kata. 2) Keterampilan pemahaman. 3) Keterampilan belajar.

Dalam kaitannya dengan jenis membaca, Al Khuli (1986: 113) membagi membaca ke dalam lima bagian yaitu; 1) membaca intensif, 2) membaca ekstensif, 3) membaca diam, 4) membaca keras, dan 5) membaca dengan tuntunan. Menurut Nugraha (2008), terdapat 3 jenis membaca di dalam kehidupan sehari-hari dilihat dari apa tujuan proses membaca tersebut, antara lain; 1) membaca sebagai hiburan tanpa perlu memeras otak terlalu keras, 2) membaca untuk memperoleh ilmu pengetahuan, dan 3) membaca 
kritis. Sedangkan menurut Effendy (2005: 158-164), ada beberapa jenis kegiatan membaca, antara lain; 1) membaca keras (القراءة الجهرية), 2) membaca dalam hati ( القراءة (الصامتة), 4) membaca cepat (القراءة السريعة), 4) membaca rekreatif (5) (القرة الاستمتاعية), membaca analitis (القراءة التحليلية).

\section{Pengajaran Kemahiran Membaca}

Kemahiran membaca mengandung dua aspek/pengertian. Pertama, mengubah lambang tulis menjadi bunyi. Kedua, menangkap arti dari seluruh situasi yang dilambangkan dengan lambang-lambang tulis dan bunyi tersebut (Effendy, 2005: 127).

\section{Kemahiran mengubah lambang tulis menjadi bunyi}

Abjad Arab mempunyai sistem yang berbeda dengan abjad Latin. Abjad Arab bersifat "sillabary" sedangkan abjad Latin bersifat "alphabetic". Perbedaan lain adalah sistem penulisan bahasa Arab yang dimulai dari kanan kekiri, tidak dikenalnya huruf besar dengan bentuk tertentu untuk memulai kalimat baru, menulis nama orang atau tempat, dan perbedaan bentuk huruf-huruf Arab ketika berdiri sendiri, di awal, di tengah dan di akhir.

\section{Kemahiran memahami makna bacaan}

Aspek ini merupakan inti dari kemahiran membaca. Ada tiga unsur yang harus diperhatikan dan dikembangkan dalam pelajaran membaca untuk pemahaman ini, yaitu unsur kata, kalimat dan paraf. Ketiga unsur ini bersamasama mendukung makna dari suatu bahan bacaan.

Secara umum, tujuan pengajaran membaca adalah agar siswa dapat membaca dan memahami teks bahasa Arab. Ada beberapa metode yang dapat diterapkan dalam pengajaran membaca, diantaranya; 1) metode huruf, 2) metode suara, 3) metode suku kata, 4) metode kata, 5) metode kalimat, dan 6) metode campuran (Al Khuli, 1986: 107-112).

\section{Pelaksanaan Pembelajaran Membaca Teks Bahasa Arab dengan Teknik Taking Notes Mahasiswa PBA IAIM NU Metro}

Penelitian ini dilaksanakan dengan 2 siklus, setiap silkusnya dilaksanakan melalui 4 tahap, yaitu: 1) perencanaan tindakan, 2) pelaksanaan tindakan, 3) pengamatan atau observasi, dan 4) refleksi. 
Hasil Observasi Aktivitas Dosen Selama Proses Pembelajaran dengan Teknik Taking Notes Siklus I.

Analisis data hasil observasi (pengamatan) menggunakan analisis persentase, dengan kualifikasi sangat baik skor 4, baik skor 3, cukup skor 2, dan kurang skor 1 . Skor yang muncul terhadap masing-masing deskriptor dijumlahkan dan hasilnya disebut jumlah skor. Kemudian dihitung nilai rata-rata dengan rumus sebagai berikut:

Skor Maksimum Dosen : 65

Persentase Nilai Rata-rata $=\frac{\text { Skor Perolehan }}{\text { Skor Maksimum }} \times 100 \%$

Dari hasil pengamatan observer yaitu dosen mitra terhadap aktivitas dosen yaitu peneliti dalam strategi kognitif teknik taking notes pada tindakan siklus I jumlah skor yang diperoleh adalah 45 sedangkan skor maksimal adalah 65 berdasarkan hasil data pengamatan tersebut, maka persentase nilai rata-ratanya adalah $\frac{46}{65} \times 100 \%=71 \%$, dengan hasil tingkat penguasaan kemampuan tersebut termasuk dalam kategori B. Berdasarkan tabel deskriptor, dalam pelaksanaan pembelajaran ini peneliti lebih dominan menggunakan langkah pembelajaran ceramah, dengan itu menyebabkan kurangnya interaksi pembelajaran antar mahasiswa.

\section{Hasil Observasi Aktivitas Mahasiswa Selama Proses Pembelajaran dengan Teknik}

\section{Taking Notes Siklus I.}

Seperti halnya hasil observasi kegiatan dosen, analisis data hasil observasi kegiatan mahasiswa juga menggunakan analisis persentase, dengan kualifikasi sangat baik skor 4, baik skor 3, cukup skor 2, dan kurang skor 1 . Skor yang muncul terhadap masing-masing deskriptor dijumlahkan dan hasilnya disebut jumlah skor. Kemudian dihitung nilai rata-rata dengan rumus sebagai berikut:

Skor Maksimum Mahasiswa: 55

Persentase Nilai Rata-rata $=\frac{\text { Skor Perolehan }}{\text { Skor Maksimum }} \times 100 \%$

Dari hasil pengamatan observer yaitu dosen mitra terhadap aktivitas mahasiswa pada tindakan siklus I jumlah skor yang diperoleh adalah 40 sedangkan skor maksimal adalah 55 berdasarkan hasil data pengamatan tersebut, maka persentase nilai rataratanya adalah $\frac{40}{55} \times 100 \%=73 \%$, dengan hasil tersebut tingkat responsif mahasiswa 
dalam proses belajar mengajar termasuk dalam kategori Baik. Berdasarkan tabel deskriptor, mahasiswa kurang mengembangkan pengetahuan awal yang telah diperoleh sebelumnya dan juga kurang memperhatikan penjelasan dosen. Selain itu ada beberapa mahasiswa yang tidak mau mencatat kosakata sulit yang telah mereka tanyakan. Akan tetapi pada dasarnya mahasiswa sudah cukup baik dalam mengikuti kegiatan pembelajaran dengan langkah pembelajaran yang digunakan oleh dosen. Beberapa hal tersebut akan dilakukan perbaikan oleh peneliti dalam siklus berikutnya.

\section{Tahap Analisis dan Refleksi Tindakan 1}

Berdasarkan hasil observasi oleh dosen mitra tersebut, pada siklus I ini aktivitas dosen sudah baik dan telah menunjukkan adanya praktik pembelajaran yang sudah sesuai dengan rencana pelaksanaan pembelajaran yang telah disiapkan. Akan tetapi ada beberapa catatan yang perlu adanya perbaikan. Sesi membaca nyaring yang memakan waktu lama karena sering kali mahasiswa diminta untuk mengulang bacaannya yang kurang nyaring. Hal ini yang membuat mahasiswa terlihat jenuh dan capek. Diharapkan pada siklus berikutnya hal ini dapat diantisipasi dengan menekankan kepada mahasiswa untuk lebih siap dalam membaca nyaring. Begitu pula dengan variasi pembelajaran dan aloksi waktu yang digunakan untuk setiap tahapannya. Hal ini dilakukan sebagai upaya untuk selalu menciptakan suasana pembelajaran yang menyenangkan.

Berdasarkan hasil observasi, dapat diketahui bahwa rata-rata dari nilai tes yang mencakup penguasaan pemahaman teks bahasa Arab sebelum diterapkannya strategi kognitif dengan teknik taking notes adalah 45 dan persentasenya adalah $45 \%$. Setelah diterapkannya strategi kognitif dengan teknik taking notes, hasil rata-rata dari nilai tes akhir dalam siklus I adalah 79 dan persentasenya 79\%.

Peneliti menyimpulkan dalam tindakan 1, 2, dan 3 pada siklus pertama ini adalah, bahwa proses adaptasi mahasiswa sudah baik meskipun masih ada beberapa mahasiswa yang masih kurang antusias dalam mengikuti teknik pembelajaran yang dilaksanakan guru. Hal ini mungkin disebabkan karena mahasiswa belum terbiasa dengan variasi-variasi pembelajaran yang sebelumnya belum pernah diterapkan dalam pembelajaran bahasa Arab. 
Hasil Observasi Aktivitas Dosen Selama Proses Pembelajaran dengan Teknik Taking Notes Siklus II.

Analisis data hasil observasi (pengamatan) menggunakan analisis persentase, dengan kualifikasi sangat baik skor 4, baik skor 3, cukup skor 2, dan kurang skor 1 . Skor yang muncul terhadap masing-masing deskriptor dijumlahkan dan hasilnya disebut jumlah skor. Kemudian dihitung nilai rata-rata dengan rumus sebagai berikut:

Skor Maksimum Dosen : 65

Persentase Nilai Rata-rata $=\frac{\text { Skor Perolehan }}{\text { Skor Maksimum }} \times 100 \%$

Dari hasil pengamatan observer yaitu dosen mitra terhadap aktivitas dosen yaitu peneliti dalam strategi kognitif teknik taking notes pada tindakan siklus II jumlah skor yang diperoleh adalah 45 sedangkan skor maksimal adalah 65 berdasarkan hasil data pengamatan tersebut, maka persentase nilai rata-ratanya adalah $\frac{45}{65} \times 100 \%=80 \%$, dengan hasil tingkat penguasaan kemampuan tersebut termasuk dalam kategori A. Berdasarkan tabel deskriptor, peneliti dalam pelaksanaan pembelajaran sudah sangat baik dalam memberikan materi pelajaran juga dalam mengedrilkan materi Qira'ah secara berulang-ulang dengan suara nyaring. Dosen (peneliti) juga telah memperbaiki langkah pembelajaran dengan tidak monoton ceramah melainkan dengan Tanya jawab, sehingga membuat pola interaksi pembelajaran yang dilakukan menjadi lebih baik.

\section{Hasil Observasi Aktivitas Mahaiswa Selama Proses Pembelajaran dengan Teknik Taking Notes SiklusII.}

Seperti halnya hasil observasi kegiatan dosen, analisis data hasil observasi kegiatan mahasiswa juga menggunakan analisis persentase, dengan kualifikasi sangat baik skor 4, baik skor 3, cukup skor 2, dan kurang skor 1. Skor yang muncul terhadap masing-masing deskriptor dijumlahkan dan hasilnya disebut jumlah skor. Kemudian dihitung nilai rata-rata dengan rumus sebagai berikut:

Skor Maksimum Mahasiswa: 55

Persentase Nilai Rata-rata $=\frac{\text { Skor Perolehan }}{\text { Skor Maksimum }} \times 100 \%$

Dari hasil pengamatan dosen mitra sebagai observer terhadap aktivitas mahasiswa pada tindakan siklus II jumlah skor yang diperoleh adalah 45 sedangkan 
skor maksimal adalah 55 berdasarkan hasil data pengamatan tersebut, maka persentase

nilai rata-ratanya adalah $\frac{45}{55} \times 100 \%=82 \%$, hal ini dapat diartikan berdasarkan hasil observasi (pengamatan) dosen mitra pada proses pembelajaran, tingkat responsif mahasiswa dalam proses belajar mengajar termasuk dalam kategori Sangat Baik. Mahasiswa dinilai sangat baik sekali dalam memperhatikan setiap penjelasan yang disampaikan dosen dan mahasiswa juga sudah cukup dalam mengembangkan pengetahuan awal yang telah diperoleh sebelumnya. Jadi mahasiswa sudah sangat baik dalam mengikuti kegiatan pembelajaran dengan langkah pembelajaran yang digunakan oleh dosen.

\section{Tahap Analisis dan Refleksi Tindakan II}

Berdasarkan hasil observasi oleh dosen mitra tersebut, pada siklus 2 ini aktivitas dosen sudah baik dan telah menunjukkan adanya praktik pembelajaran yang sudah sesuai dengan rencana pelaksanaan pembelajaran yang telah disiapkan. Peneliti sebagai dosen juga melakukan perbaikan dari hasil refleksi dalam tindakan 1, yaitu dengan mengkondisikan mahasiswa selama pembelajaran berlangsung, terutama pada sesi membaca nyaring. Mahasiswa terlihat lebih siap dan tidak mudah jenuh/capek ketika kegiatan membaca nyaring.

Berdasarkan hasil observasi, dapat diketahui bahwa rata-rata dari nilai tes yang mencakup penguasaan pemahaman teks bahasa Arab setelah diterapkannya strategi kognitif dengan teknik taking notes, hasil rata-rata dari nilai tes akhir dalam siklus II adalah 86 dan persentasenya $86 \%$.

Secara keseluruhan hasil observasi pada siklus II ini menunjukkan bahwa mahasiswa menjadi lebih aktif dan bersemangat untuk mengikuti pelajaran bahasa Arab. Menurut hasil wawancara kepada dosen mitra dan beberapa orang mahasiswa , pada proses tindakan dan setelah tindakan, diketahui bahwa kegiatan proses belajar mengajar lebih meningkat/baik dari siklus I. Hal ini terlihat dari hasil wawancara kepada dosen mitra bahwa seluruh mahasiswa terlihar antusias dan lebih berkonsentrasi dalam mengikuti pelajaran bahasa Arab, padahal sebelumnya mereka suka tidak memperhatikan dosen dan tidak bisa menjawab pertanyaan dari dosen.

Sedangkan dari jawaban mahasiswa tentang kesan mereka terhadap proses belajar mengajar yang telah dilaksanakan, sebagian besar mereka merasa bahwa proses 
belajar mengajar lebih menyenangkan dan lebih mudah memahami materi setelah diterapkannya strategi kognitif dengan teknik taking notes.

Refleksi dilakukan untuk menentukan apakah tindakan siklus kedua ini sudah berhasil atau belum berdasarkan analisis data observasi yang dilakukan oleh dosen mitra terhadap aktivitas peneliti menunjukkan taraf keberhasilan dalam kategori A dan juga berdasarkan analisis data observasi yang dilakukan pengamat terhadap aktivitas mahasiswa menunjukkan taraf keberhasilan kualitas sangat baik. Pada siklus II peneliti sudah maksimal dalam melakukan kegiatan proses belajar mengajar di kelas, hal ini ditunjukkan dengan suasana kelas yang sangat tenang ketika dosen menjelaskan pelajaran/mengerjakan kuis dan suasana lebih hidup ketika kegiatan Tanya jawab.

Dalam pelaksanaan pembelajaran strategi kognitif dengan teknik taking notes pada siklus II ini, dapat disimpulkan bahwa kemampuan penguasaan pemahaman teks bahasa Arab mahasiswa sudah meningkat. Ini dapat dilihat dari lampiran hasil rata-rata skor postes siklus II yaitu 86 dengan persentase $86 \%$.

Dengan meningkatnya kemampuan pemahaman teks bahasa Arab mahasiswa pendidikan bahasa Arab semester IV setelah dilakukan siklus II, maka penerapan strategi kognitif teknik taking notes pada materi الطعام والشرب untuk meningkatkan kemampuan membaca teks bahasa Arab dianggap cukup dan dihentikan sampai pada siklus II ini. Penghentian siklus ini didasarkan pada hasil penilaian postes dan lembar observasi yang diisi oleh dosen mitra. Peningkatan ini dilihat pada siklus II ini nilai ratarata kemampuan membaca bahasa Arab sudah meningkat yaitu 86.

\section{Hasil Peningkatan Penguasaan Membaca Teks Bahasa Arab Mahasiswa PBA Melalui Penggunaan Teknik Taking Notes}

Berdasarkan hasil analisis tes dan wawancara yang diambil pada setiap akhir siklus, didapatkan data sebagai berikut:

\section{Siklus I}

Data hasil peningkatan kemampuan membaca teks bahasa Arab setelah diterapkannya strategi kognitif dengan teknik taking notes diperoleh dari hasil postes yang dilakukan pada akhir pertemuan siklus I yang diikuti oleh 11 mahasiswa. Data hasil postes secara lengkap disajikan dalam lampiran. Secara ringkas disajikan pada tabel. 
Tabel 3. Persentase Hasil Postes Mahasiswa Pada Siklus I

\begin{tabular}{cccc}
\hline $\begin{array}{r}\text { Jumlah } \\
\text { mahasiswa }\end{array}$ & $\begin{array}{c}\text { Hasil skor rata- } \\
\text { rata }\end{array}$ & Persentase & $\begin{array}{c}\text { Persentase } \\
\text { ketuntasan }\end{array}$ \\
\hline 11 & 79 & $79 \%$ & $87 \%$ \\
\hline
\end{tabular}

Berdasarkan tabel diatas dapat diketahui bahwa pada siklus I mahasiswa semester IV yang berjumlah 11 berhasil mencapai skor rata-rata 71. Akan tetapi masih ada 2 mahasiswa yang belum tuntas belajar, sehingga diperoleh hasil persentase ketuntasan 87\%. Dengan hasil rata-rata kelas yang mencapai 79 dapat diartikan bahwa mahasiswa semester IV dianggap tuntas belajar dalam pembelajaran bahasa Arab.

\section{Siklus II}

Data hasil peningkatan kemampuan membaca teks bahasa Arab setelah diterapkannya strategi kognitif dengan teknik taking notes diperoleh dari hasil postes yang dilakukan pada akhir pertemuan siklus II yang diikuti oleh 11 mahasiswa. Data hasil postes secara lengkap disajikan dalam lampiran. Secara ringkas disajikan pada tabel.

Tabel 4. Persentase Hasil Postes Siswa Pada Siklus II

\begin{tabular}{cccc}
\hline $\begin{array}{c}\text { Jumlah } \\
\text { siswa }\end{array}$ & $\begin{array}{c}\text { Hasil skor rata- } \\
\text { rata }\end{array}$ & Persentase & $\begin{array}{c}\text { Persentase } \\
\text { ketuntasan }\end{array}$ \\
\hline 11 & 86 & $86 \%$ & $95 \%$ \\
\hline
\end{tabular}

Berdasarkan tabel diatas dapat diketahui bahwa pada siklus II mahasiswa semester IV yang berjumlah 11 berhasil mencapai skor rata-rata 86. Semua mahasiswa sudah tuntas belajar, sehingga diperoleh hasil persentase ketuntasan 95\%. Dengan hasil rata-rata kelas yang mencapai 86 dapat diartikan bahwa mahasiswa semester IV dianggap tuntas belajar dalam pembelajaran bahasa Arab dengan Kriteria Ketuntasan Minimal (KKM) yang telah ditetapkan adalah 65.

Data dari hasil wawancara dengan mahasiswa dapat disimpulkan bahwa melalui strategi kognitif dengan teknik taking notes ini mereka mampu memahami teks bahasa Arab dengan lebih mudah. Dengan bantuan media kartu dan tabel taking notes yang dipakai dalam pembelajaran sangat membantu mereka dalam memahami wacana /teks bahasa Arab tanpa harus dengan teknik penerjemahan ke dalam bahasa Indonesia. 
Tingkat kemampuan pemahaman teks bahasa Arab mereka lebih maksimal dibandingkan sebelum diterapkannya teknik taking notes.

\section{Perbandingan Siklus I dan Siklus II}

Berdasarkan hasil perbandingan dari hasil nilai pada siklus 1 dan 2, diperoleh bahwa hasil pemahaman teks bahasa Arab mahasiswa mengalami peningkatan. Perbandingan hasil nilai postes siswa siklus 1 dan 2 disajikan pada tabel.

Tabel 5. Perbandingan Rata-Rata Hasil Postes Siswa Pada Siklus 1 dan 2

\begin{tabular}{ccc}
\hline HP1 & HP2 & Peningkatan (\%) \\
\hline 79 & 86 & $7 \%$ \\
\hline
\end{tabular}

\section{Keterangan :}

HP1 : rata-rata hasil postes siklus 1

HP2 : rata-rata hasil postes siklus 2

Berdasarkan tabel di atas dapat diketahui bahwa persentase rata-rata hasil postes pemahaman teks bahasa Arab mahasiswa meningkat dari siklus 1 ke siklus 2 yaitu sebesar 7\%. Untuk lebih mudahnya mengetahui perkembangan dan kenaikan dari hasil tes awal sampai siklus II, dapat dilihat dari grafik dibawah ini.

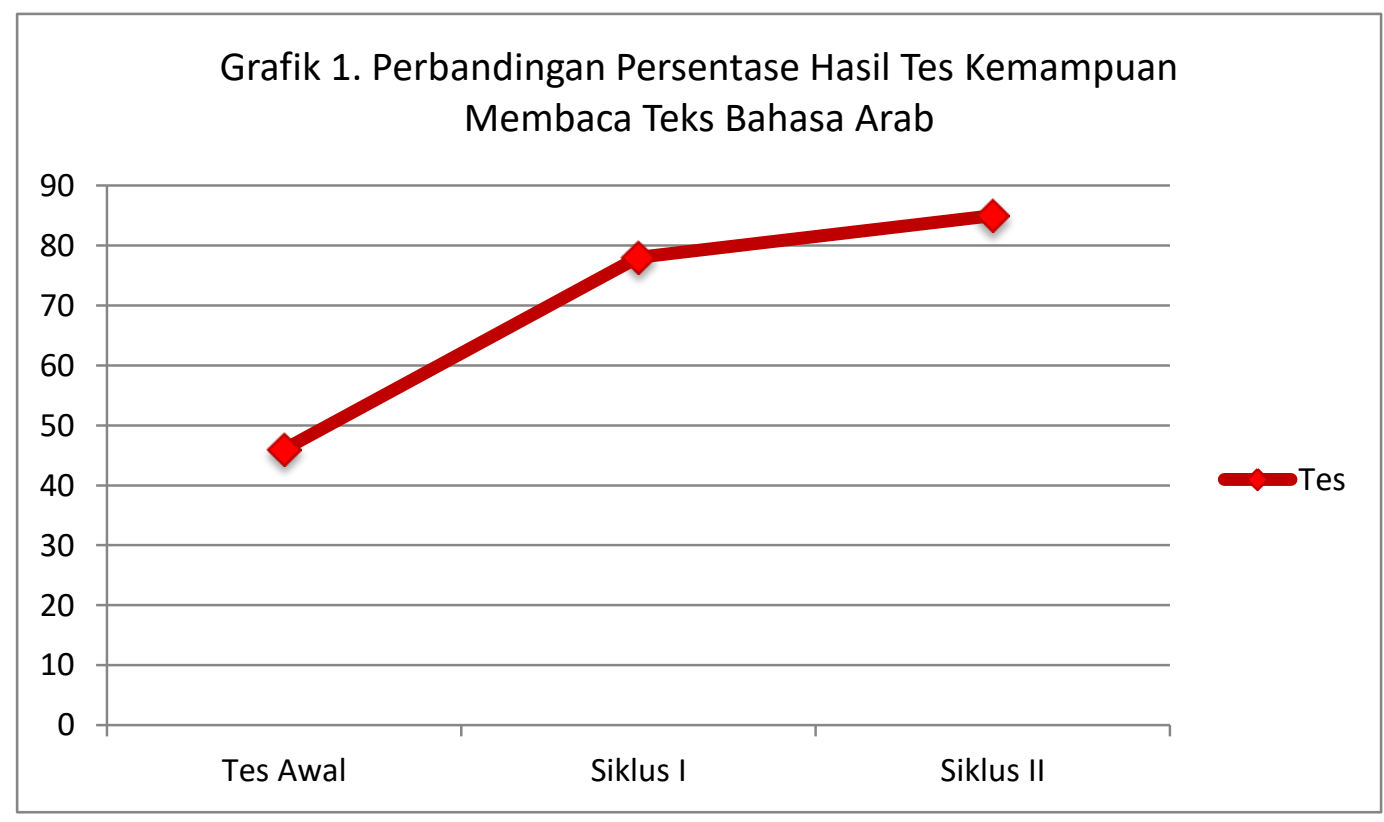

Dari grafik di atas dapat diketahui adanya peningkatan kemampuan membaca teks bahasa Arab mahasiswa. Pada setiap siklus mengalami kenaikan yang cukup signifikan, yakni sebelum dilakukan tindakan hasil belajar mahasiswa rata-rata hanya $45 \%$ setelah 
akhir tindakan pada siklus I rata-rata 79\%, dan siklus II rata-rata $86 \%$. Kenaikan tersebut merupakan suatu realita bahwa strategi kognitif dengan teknik taking notes dapat meningkatkan kemampuan membaca teks bahasa Arab mahasiswa.

\section{Kesimpulan}

Pelaksanaan pembelajaran membaca teks bahasa Arab dengan strategi kognitif teknik taking notes mahasiswa semester IV terdapat bagian-bagian yang dapat meningkatkan aspek-aspek kemampuan mahasiswa dalam pembelajaran membaca. 1) sesi membaca nyaring, dimana mahasiswa didorong untuk dapat membaca dengan makhraj dan intonasi yang benar. 2) sesi mengisi tabel taking notes, hal itu dilakukan untuk memudahkan mahasiswa dalam memahami teks bacaan. 3) sesi membuat kalimat sederhana/menjawab tes, hal tersebut dilakukan untuk mengukur sejauh mana pemahaman mahasiswa terhadap isi dari teks bahasa Arab.

Pada siklus I ditemukan beberapa permasalahan, antara lain: mahasiswa belum terkondisikan karena acuan yang diberikan oleh dosen pada awal pertemuan kurang jelas, dan mahasiswa merasa cepat jenuh dan mudah capek ketika sesi membaca nyaring. Setelah dilakukan refleksi, permasalahan yang di temukan pada siklus I tersebut dapat diatasi pada siklus II.

Setelah dilakukan penerapan strategi kognitif dengan teknik taking notes terdapat peningkatan kemampuan membaca teks bahasa Arab mahasiswa, diketahui dengan adanya peningkatan yang baik dari siklus I sampai siklus II, dengan persentase peningkatan $7 \%$. Peningkatan tersebut diukur dengan adanya tes akhir dalam setiap siklusnya.

Berdasarkan hasil penelitian yang telah dilakukan maka peneliti memberikan beberapa saran kepada pihak-pihak yang terkait sebagai berikut: 1) Dosen mata kuliah Qiro'ah, sebaiknya menggunakan teknik pembelajaran yang bervariasi dalam kegiatan belajar mengajar, agar mahasiswa tidak bosan/ mengalami kejenuhan dalam belajar dan membantu memudahkan mahasiswa dalam memahai pelajaran. Salah satu teknik pembelajaran yang dapat digunakan adalah teknik taking notes, teknik pembelajaran ini telah dibuktikan dalam penelitian ini bisa meningkatkan kemampuan membaca teks bahasa Arab mahasiswa. 2) Peneliti selanjutnya, untuk penelitian yang akan menggunakan strategi kognitif teknik taking notes sebaiknya diterapkan pada kemahiran bahasa Arab yang lain. 


\section{Daftar Rujukan}

Ainin, M. \& Tohir, M. \& Asrori, Imam. Evaluasi dalam Pembelajaran Bahasa Arab. Malang: IKIP Malang, 2006.

Ainin, Moch. Metodologi Penelitian Bahasa Arab. Malang: Hilal Pustaka, 2007.

Al Abdullah, A. F. Asasu Ta'lim Al-Qira'ah Al-Naqidah Li Al-Thalabah Al-Mutafawwiqun Aqliyyan. Yordania: 'Alim Al Kutub Al Hadits, 2007.

Al Khuli, M. A. Asalib Tadris Al Lughah Al Arabiyah. Kairo: Jami' Al Huquq, 1986.

Effendy, Fuad. Metodologi Pengajaran Bahasa Arab. Malang: Misykat, 2009.

Elliot, J. Action Research For Educational Change. Buckingham: Open University Press, 1992.

Fakhruddin, Agus Abid. Peningkatan Kemampuan Membaca Bahasa Arab Siswa Kelas VIII dengan Permainan Kartu "Rangkai" di SMP Plus Hidayatullah Mubtadiin Singosari Malang. Skripsi: Tidak di Terbitkan. Malang: FS UM, 2009.

Kementrian Pendidikan Nasional UM. Pedoman Pendidikan UM. Malang: Universitas Negeri Malang, 2010.

Nugraha, E. S. Cara Membaca Yang Menyenangkan (online). (www.sekolahindonesia.com). 2008.

Nurhidayati \& Anisah. Strategi Pembelajaran Bahasa Arab Untuk Anak. Malang: Fakultas Sastra UM, 2005.

Oxford, R. L. Language Learning Strategies. What Every Teacher Should Know. USA: Newbury House Publishers, 1990.

Ristianah, Nina. Penerapan Metode Pembelajaran Model Teams Games Tournament (TGT) Untuk Meningkatkan Hasil Belajar Akuntansi Siswa Kelas X-A Program Keahlian Akuntansi SMK Shalahuddin Malang. Malang: Fakultas Teknik UM, 2007.

Wahidmurni \& Nur Ali. Penelitian Tindakan Kelas. Malang: UM Press, 2008.

Yamin, Martinis. Paradigma Pendidikan Konstruktivistik. Jakarta: Gaung Persada Press, 2008.

$$
\begin{aligned}
& \text { الحميدة، حسنة. تطبيق الطريقة التعاونية باستحلام لعب المبارات الغئوية لتتقية المهارة الطلبة وغغبتهم } \\
& \text { في القرأة بحث التجريبي بالملدسة الثانوبة الإسلامية الحلكومية جوندانج ليجى مالانج. البحث } \\
& \text { العلمي. كلية الآدب، جامعة مالانج الحلكومية، و . . ب. } \\
& \text { الزهرة، رحة. تطبيق أسلوب "طرح الأسئة" في تعليم القرأة لتققية الزغبة والتحصيل الدراسي للى } \\
& \text { طلبة الصف الثاني في الملدرسة الثانوية العامة "دار القرآن" سنغا سارى. البحث العلمي. كلية }
\end{aligned}
$$

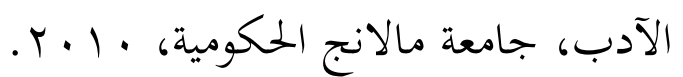

